eastern portion of the State from the same host plants, although the hosts themselves are very abundant in some cases. Grindelia squarrosa, Dund., ranges over the entire State in abundance, but Puccinia grinäelice, Pk., has never, to my knowledge, been found east of Russell and Rooks Counties. Another singular fact is that I never found it on the variety grandiflora, Gr., which grows so abundantly in western Kansas. Uredo gaurina, Pk., and its Aecidium, too, are found in the western counties only, although three species of Gaura are native in eastern Kansas. Lygodesmia juncea, though not widely diffused in the eastern portion of the State, is still rather abundant in spots about Manhattan, but without any fungus; while over the western counties, not only is the plant itself very common, but it supports, in great abundance, a rust which has been named Puccinia variolans, Hark, var. caulicola, Ell. and Ev. I have noticed for several years that Puccinia phragmitis (Schum.), Korn., is never found on Phragmites communis in eastern Kansas (although abundant on Spartina cynosuroides), but is common on this host wherever found in the western counties, so Uropyxis amorphce (Curt.), Schroet, abundant on both Amorpha canescens and $A$. fruticosa in the west, is found only on the former host in this region. What seems to be the Puccinia grindelice, $\mathrm{Pk}$, above mentioned, is also found on Aplopappus rubiginosus in abundance in the west but this host does not grow in this region. In these cases may there not be anatomical differences in the hosts (of the same species, even) which cause this peculiar distribution of their parasites. At least, the question is worthy of close investigation. It is another indication, to me, that plant pathology cannot be well understood without a knowledge of plant physiology. I have already shown in another article ${ }^{1}$ how the host-plants themselves vary in passing from the more fertile to the more barren districts of the great plains. The distribution of their parasites may be greatly influenced by these variations.

IN MEMORIAM. - THE REV. W. C. LUKIS, M.A., F.S.A.

BY W. GREGSON, F.G.S., BALDERSBY, S. O., YORISHIRE, ENG

The death of the Rev. William Collings Lukis removes a familiar figure from the ranks of British scientists, and one who will long be remembered with feelings of deepest respect and esteem, not only in Great Britain, where he lived and worked so long, but throughout the whole of the scientific world. His tall, erect, manly form, and genial countenance, were well known throughout Yorkshire, and he was certainly one whose friendship it was a pleasure and a delight to claim.

Mr. Lukis was not only an archæologist of world-wide eminence but was also a considerable authority on geology, botany and other branches of natural science. He had long been an observant travelfer in various parts of Europe, Africa, America, etc. More especially in the Netherlands, Denmark, France, Italy, and Algeria; and his writings and researches show that accurate and intimate knowledge of those countries which he acquired from careful personal investigations. The deceased gentleman was also an artist of considerable power and merit, as many of his works, illustrated by his own hand, sufficiently testify. He was born on April 8th, 181\%, in the Island of Guernsey (English Channel), and was the third son of Colonel Frederick Corben Lukis, by Elizabeth, youngest daughter of Mr. John Collings of Guernsey. From his father, who was also an archæologist of distinction, Mr. Lukis inherited a taste for natural science, which he pursued at the University of Cambridge, under Professors Henslow and Sedgwick, and the writer has frequently heard him dilate on the benefits he derived from his connection with such far-famed scientists. He received his early education in Guernsey, afterwards in France, and at Blackheath, near London, under the mastership of the Rev. Sanderson Tennant, whilst in January, 1840, he graduated in honors at Trinity College, Cambridge. Twelve months later he was ordained at Salisbury, by Bishop Denison, and licensed to the curacy of Bradford-on-Avon (of which parish the late famous Harvey, formerly private tutor to Prince George, now Duke of Cambridge, was then vicar). In

1 “Contrib. U. S. Nat. Herb.," vol. XxI., No. 6, pp, 220-232.
1845, he was appointed chaplain to the Marquis of Ailesbury, who successively presented to him the livings of Great Bedwyn, and Collingbowne Ducis in Wiltshire, and Wath, near Ripon, in Yorkshire; which latter he held for thirty-one years up till the time of his death. Whilst residing at Cambridge he was one of the earliest members of and contributors to the Camden Society, then newly formed, and when living at Bradford-on-Avon, he published a quarto volume on "Ancient Church Plate," also other works on " Church Bells," "Church Towers," etc.

In 1847 he was elected a Fellow of the Royal Society of Northern Antiquaries, Copenhagen; in 1853, a Fellow of the Society of Antiquaries, of London; and in 1867, a member of the Societé Archéologique de Nantes, whilst in 1872, he was elected a corresponding member of the Société de Climatologie Algerienne. $\mathrm{Mr}$. Lukis was the author of many works on barrows, and other prehistoric monuments, and was a practical barrow digger on an extensive scale, in various parts of England, France, Denmark, the Netherlands, and elsewhere. The Society of Antiquaries, London, published his scale plans of Rude Stone Monuments, with descriptive text. He also edited, for the Surtees Society, Dr. William Stukeley's Diaries and Letters, published in three volumes; and when the Ripon Millenary Festival was celebrated, in 1886, he was an active membor of the committee, which was formed to carry out the arrangements, and wrote an interesting and valuable article entitled "Ancient Ripon," since included in Mr. W. Harrison's "Millenary Record" (a beautifully illustrated volume published at Ripon, in 1892).

Mr. Lukis, who was a prominent Free Mason, and a J.P. for Wiltshire, married Lucy Adelaide, daughter of Admiral Sir Thomas Fellowes, who survives her husband, and by whom he leaves two sons and four daughters; the eldest daughter being the wife of a son of the late Canon Hawkins, J.P., of Topcliffe, Yorks (a relative of Mr. Justice Hawkins), and the second daughter being the wife of Mr. H. C. Bickersteth (son of the late Bishop of Ripon, nephew of the Bishop of Exeter, and cousin of the Bishop of Japan).

A committee has recently been formed, under the chairmanship of Sir Reginald Graham, Bart., of Norton-Conyers, near Ripon (which is close to Wath, and where the talented authoress of "Jane Eyre" at one time resided), for the purpose of placing in Wath Parish church a strained-glass window, as a lasting memorial of the late much esteemed rector, who was so ripe a scholar, so kind a friend, and of whom it may be truly recorded: -

He seemed the thing he was, and joined

Each office of the social hour

To noble manners, as the flower

And native growth of noble mind.

\section{OBSERVATIONS ON DUCKLINGS.}

BY C. LLOYD MORGAN, BRISTOL, ENGLAND.

OF seven eggs transferred from a hen to my incubator only two hatched out. Of the others four had not been fertilized and the fifth contained a dead bird in about its tenth day of incubation. Several hours before the ducklings chipped the shell they were piping to be free. One (A) was hatched four hours before the other (B). They were left in the drawer of the incubator for about 20 to 24 hours, and were then transferred to an experimental poultry yard in my study. Somewhat unsteady upon their legs, they kept tilting backwards on to their tails; but A was decidedly the stronger of the two and his motor coördination was better. They pecked with uncertain aim at anything which caught their eyes, such as marks on the basket in which they were to sleep, grain, sand. Chopped-up white of egg was placed before them and moved about with a long pin to draw their attention to it. The coördination for pecking was far from perfect. When a piece was seized after several shots it was mumbled rapidly and then shaken out of the bill unswallowed. A shallow tin of water was placed before them. They took no heed of it. As they tottered about they walked through it several times, but no notice was taken. I dipped A's beak into the water. He drank with characteristic action; he then pecked at 
the water repeatedly and drank. Presently B imitated him, and he too drank repeatedly. Both pecked at white of egg held in forceps, seizing at about the third shot, but shook it out of the bill. Perbaps some was swallowed. I then put them to bed in their basket. .

Two hours later they were taken out and waddled about with more accuracy of motor coördination. When they came to the water they both at once drank. They pecked at white of egg placed on a black tray to make it more conspicuous, but shook it out of their bills.

After another two hours A was dropped into a fairly deep bath. He floated and kicked vigorously, dropping. excrement. In less than a minute he swam round and round the bath and pecked at marks on the side.

A little later both made for the tin of water and sat in it. They pecked with more accuracy and without suggestion (i. e., moving it about with pin) at white of egg on the tray, still shaking the head vigorously, but swallowing freely. A scratched his head two or three times, but tumbled over in the process.

Later in the evening of the same day they ate white of egg freely. The pecking coördination was much more accurate, but not quite accurate. I placed $B$ in the bath. He kicked excitedly and dropped excrement; then swam about vigorously, pecking at the sides.

Next morning when taken from their basket both $\mathrm{A}$ and $\mathrm{B}$ made for the water in their tin and drank and sat in it. They ate keenly of white of egg, swallowing large morsels. Both scratched their heads occasionally, tumbling down. Both preened their down, rubbing their bills over their breasts. They applied their bills to the base of the tail and rubbed their heads along their backs in the most approved duck fashion. They stood up and clapped their downy winglets, toppling over backwards on to their tails from imperfect coördination.

In the middle of the day I placed a blue-bottle fly, from which the wings had been snipped off, near them. A followed, pecking at it, but failed to seize. It escaped under the newspaper which formed the floor of my yard. I routed it out. A again followed pecking, but the fly escaped through the wire netting. I placed it again in the yard. A followed and caught it at the third peck, swallowing it apparently with satisfaction. Put A in the basket. $B$ then caught another fly after numerous abortive attempts.

Both A and B ate their own excrement and that of chicks, showing less signs of dislike than do chicks.

Tried the ducks with all sorts of odd things, bits of paper, chopped-up matches, leaves, flowers, small stones, red currants, anything of suitable size I could lay hands on. Each was seized and mumbied, and then either rejected or swallowed.

When three days old I threw to them the yellow and blackbanded caterpillar of the cinnabar moth. Each seized it, but dropped it at once. Very soon no notice was taken of it. Next day on repeating the experiment $A$ seized a caterpillar, but dropped it. B took no notice. They ate freely of green caterpillars from gooseberry bushes, and distinguished between these nice morsels and the nasty yellow and black caterpillars. They ate tadpoles placed in their water, noticing them directly they began to swim about.

I daily placed for them at about 9 A.M. in my experimental yard a large black tray with a shallow tin of water. To this they at once ran and drank, sitting in the water and washing. On the sixth day I put down the tray and tin as usual; but the tin was empty. They ran to it, went tbrough all the action of mumbling the water and drinking. They sat in the empty tin wagging their little tails and ducking down their heads as if they were enjoying a good bath. They continued this procedure for about ten minutes. I then gave them some water. The next morning I repeated the same experiment, but though the ducks searched for water with their bills they did so with less vigor and zest.

A winged bee was thrown in. B seized it, but dropped it. A seized it, and after mumbling it for a moment, swallowed it. Possibly he was stung. He kept on scratching the base of bis beak first on one side then on the other and seemed uneasy. But he was all right again in half an hour. There was no instinctive avoidance of bees. Subsequently he would not touch a bee. There was an intelligent avoidance of bees. Nor would they touch the bee-like fly, Eristalis. Its mimetic form served as a protective character.

Subsequently A seized a humblebee and after mumbling it in the water swallowed it and seemed none the worse.

The above jottings are extracted from my note-book and are given without comment. I may add that as compared with chicks the ducklings show less intelligence and develop psychically more slowly. Their greediness and vulgarity are painful to observe and to contemplate.

\section{BACTERIA IN HEN'S EGGS.}

\author{
BY MELVIN A. BRANNON, FORT WAYNE, IND.
}

That cider should turn to vinegar and milk become sour excites little wonder among common people or even individuals of considerable education. The mere statement of fact in such ordinary phenomena seems to satisfy the masses, but fortunately for scientific and sanitary interests, there is a class of individuals persistently questioning such phenomena till reasonable explanations are secured. Consequently the souring of cider and milk was found to be caused by the presence of organisms which produced acetic and lactic acids, respectively, whenever the proper medium was exposed in an atmosphere of moderate temperature.

Not only hare these common but interesting phenomena, "souring" of cider and milk, been explained by the presence of bacteria, but many other phenomena, less common and more concealed, have been directly traced to the action of some form of bacteria associated with the matter in which the phenomena occurred.

Of course, no intelligent student bolds bacteria responsible for every chemical change in organic matter, but it is well understood and universally admitted that the greater number of chemical changes in living and decaying organic material are induced by some bacterial form.

Recognizing the importance of recording every phenomenon relating to the presence and action of bacteria, it seemed proper to recite to readers of Science some of the details in a very peculiar case recently noted.

An acquaintance whose intelligence and acuteness of observation make his testimony thoroughly reliable, stated that one of his Plymouth Rock hens was laying eggs, every one of which had an unpleasant odor, although broken a few hours after it was laid. He also said that the hen was laying regularly and appeared healthy in every respect save that she had the gaps.. A few dass succeeding this statement he reported the fowl butchered and closely examined. In her craw was found a ball of threads pulled from manilla matting which she had access to. The ball entirely filled the craw and was very hard and compact, except in the central region, through which ran a cylindrical opening, affording a passage-way for the food. This ball of manilla threads and the craw gave the same offensive odor as did the eggs when broken. The heart, liver and digestive apparatus - excepting the craw-were normal in size and appearance.

A perfect egg was taken from the hen and personally examined. It looked and smelled like a perfectly fresh egg, but when broken it gave forth the same disgusting odor that had characterized her craw and previously laid eggs. This odor was exactly like that observed in decaying meat, and, had the broken egg been concealed, any person entering the laboratory would have suspected that decaying meat was exposed in that room.

The egg contents gave a strong alkaline reaction when tested with litmus paper. The general appearance of yolk and white was normal, but a portion of albumen mounted and carefully observed under the microscope, magnification 250 diameters, revealed the presence of a great number of bodies varying in shape from almost round to distinctly oblong. These forms closely resembled bacteria, but lack of time for tests and cultures made the determination of them impossible.

From these few observations and experiments it would be unscientific to definitely conclude that these eggs were decaying from the action of bacteria, but in view of the fact that the odor so closely simulated that of decaying flesh and that the egg con- 